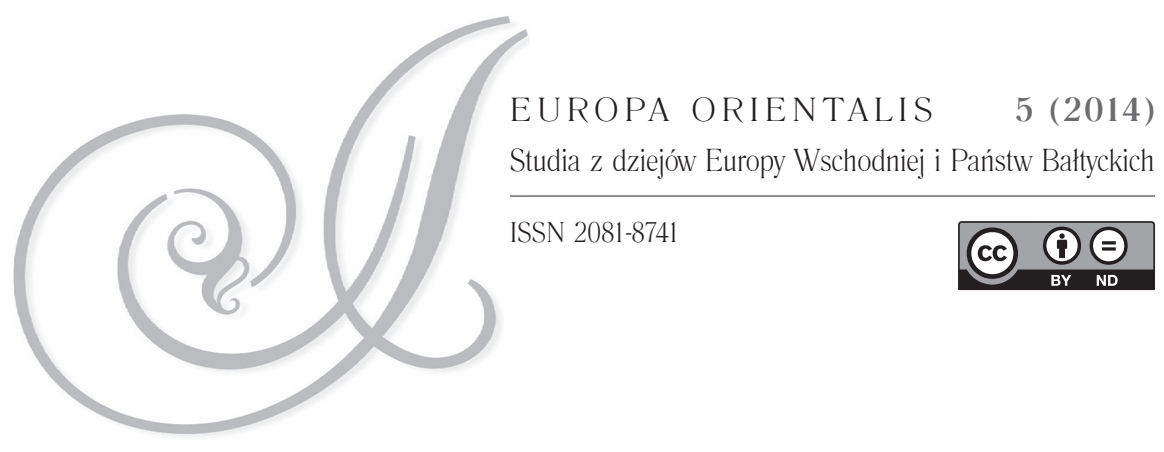

DOI: http://dx.doi.org/10.12775/EO.2014.015

\title{
XII Ogólnopolskie Forum Historyków Wojskowości w Rzeszowie
}

\ل dniach 24-27 czerwca 2014 r. w Rzeszowie odbyło się już VII Ogólnopolskie Forum Historyków Wojskowości. Organizatorem tegorocznego spotkania byłZakład Historii Wojskowej, działający w ramach Instytutu Historii Uniwersytetu Rzeszowskiego. Rzeszowskie środowisko historyków wojskowości podczas organizacji forum wspierane było przez Stowarzyszenie Historyków Wojskowości, Urząd Miasta Rzeszowa, 1 Batalion Strzelców Podhalańskich, ponadto pomoc w przeprowadzeniu samego spotkania zapewniali członkowie Stowarzyszenia Pasjonatów Piechoty Górskiej „Bielik”. Przewodniczącym komitetu organizacyjnego był dr hab. prof. UR Andrzej Olejko, funkcję sekretarza pełnił dr Paweł Korzeniowski, ponadto w składzie komitetu organizacyjnego znaleźli się dr Krzysztof Mroczkowski, mgr Damian Knutel oraz mgr Bożena Wolano.

Spotkania historyków wojskowości mają już swoją długą tradycję, odbywają się cyklicznie co 2 lata, od blisko ćwierć wieku. Poprzednie, XI OFHW, miało miejsce w Kielcach, tym razem badacze historii wojskowej zawitali do Rzeszowa. Tegoroczne spotkanie odbywało się pod hasłem „Granice, pogranicza i kresy w historii wojskowej”. Wybór takiego tematu wynikał z jednej strony z doświadczeń i zainteresowań rzeszowskiego środowiska historycznego, ale $\mathrm{z}$ drugiej $\mathrm{z}$ samego położenia miasta gospodarza, leżącego przecież blisko granicy słowackiej i ukraińskiej.

Zgodnie z postulatami przyjętymi na poprzednim spotkaniu w Kielcach, organizatorzy podjęli się przygotowania publikacji zawierającej wystąpienia 
uczestników forum, tak by przybywający do Rzeszowa uczestnicy mogli już ją otrzymać w wersji drukowanej. Założenia te udało się zrealizować, i podczas rejestracji uczestnicy otrzymali wspomnianą publikację, której redaktorami byli Olejko, Jeremiasz Ślipciec, Korzeniowski oraz Mroczkowskiego. Ponieważ nie wszyscy prelegenci byli w stanie przygotować z wyprzedzeniem teksty swoich referatów, organizatorzy zapowiedzieli przygotowanie publikacji uzupełniającej, której druk zaplanowano na przełom 2014/2015 r. Warto zaznaczyć, że uczestnicy rzeszowskiego spotkania otrzymali także publikację przygotowaną przez organizatorów poprzedniego forum, której redaktorami byli Wiesław Caban oraz Józef Smoliński (Mity i legendy w historii wojskowości, t. 1-2, Kielce 2014).

Spotkanie rozpoczęło się 25 czerwca od części oficjalnej, którą poprowadził dr hab. prof. UR Andrzej Olejko. Jako pierwszy glos zabrał dr hab. prof. Sylwester Czopek, który w imieniu gospodarza, Uniwersytetu Rzeszowskiego, przywitał przybyłych naukowców. Następnie wystąpił dr hab. prof. Zdzisław Budzyński, dziekan Wydziału SocjologicznoHistorycznego, oraz dr hab. prof. UR Jolanta Kamińska-Kwak, dyrektor Instytutu Historii. W imieniu współorganizatorów wystąpili dr hab. prof. Piotr Matusak, prezes Stowarzyszenia Historyków Wojskowości, oraz ppłk Tomasz Gdak, dowódca 1 Batalionu Strzelców Podhalańskich.

Po części oficjalnej rozpoczęto obrady sesji plenarnej, w której przewidziano 10 referatów. Jako pierwszy głos zabrał dr hab. Maciej Trąbski, który w imieniu swoim oraz prof. dr. hab. Tadeusza Srogosza przedstawił udział oficerów wojska koronnego w wytyczeniu granicy pomiędzy „Ukrainą Polską a Nowo-Rossyą” w latach 1780-1781. Następnie wystąpiła prof. dr hab. Danuta Kisielewicz i przedstawiła walkę o polsko-niemiecką granicę na obszarze Górnego Śląska (1919-1921). Następnie głos zabrał prof. dr hab. Janusz Odziemkowski, który skupił się na problematye dotyczącej ochotników z kresów północno-wschodnich w formacjach Wojska Polskiego w 1919 r. Przed pierwszą przerwą wystąpił dr hab. prof. AMW Piotr Semków, który przybliżył rolę Gdańska w systemie granicznym II Rzeczpospolitej.

Po przerwie kawowej wystapił prof. dr hab. Zygmunt Matuszak, którego referat zatytułowany był: Batalion KOP „Słobódka” - życie $i$ stużba na Kresach. Po nim głos zabrał prof. dr hab. Henryk Ćwięk, który wygłosił referat pt. Niebezpieczne sasiedztwo. O metodach działalności szpiegowskiej ZSRS wobec Drugiej Rzeczypospolitej. Po tym wystapieniu przewidziano kolejną krótką przerwę. Ostatnia część sesji plenarnej zawierała 3 referaty, mianowicie dr hab. prof. UPH Wojciech Włodarkiewicz 
omówił działania wojenne Frontu Ukraińskiego w 1939 r., dr hab. prof. AJD Jerzy Kajetanowicz scharakteryzował zagadnienia dotyczące granicy zachodniej w koncepcjach bezpieczeństwa Polski w latach 1945-1990, zaś dr hab. Halina Łach przedstawiła przemiany w ochronie polskiej granicy wschodniej w latach 1989-1991.

Po zakończeniu sesji plenarnej rozpoczęto obrady w sekcjach. Ze względu na dużą liczbę prelegentów w tym miejscu zostaną jedynie omówione główne zagadnienia poruszane na poszczególnych grupach. $\mathrm{Na}$ sekcji pierwszej tego dnia omawiano zagadnienia obejmujące szeroki zakres tematyczny i chronologiczny, rozpoczynając od pogranicza bizantyjsko-arabskiego, kończąc na połowie XVII w. i pograniczu polskotatarskim i polsko-moskiewskim. Na tej sekcji przedstawiono 8 referatów. Na drugiej sekcji obradującej tego dnia miało miejsce również 8 wystąpień, których tematyka dotyczyła przede wszystkim środkowej Europy w XIX w., oczywiście w kontekście militarnym.

Obrady sekcyjne kontynuowano następnego dnia. Pierwsza sekcja obejmowała 13 wystąpień dotyczących okresu międzywojennego, których tematyka koncentrowała się przede wszystkim na problematyce ochrony granicy II RP. W drugiej sekcji z kolei zajmowano się okresem II wojny światowej i okresem powojennym. Dwanaście referatów obejmowało swą tematyką przede wszystkim kwestie walk w okresie II wojny światowej.

Ważnym elementem XII OFHW stanowiła uroczysta kolacja, która odbyła się wieczorem 25 czerwca. Miała ona nie tylko charakter towarzyski, integrujący środowisko historyków wojskowości, ale w jej trakcie miało miejsce potwierdzenie wstępnych ustaleń z poprzedniego forum, dotyczących organizacji kolejnego, XIII zjazdu. Zgodnie z zapowiedziami zostanie ono zorganizowane w Gdyni, zaś tematem przewodnim mają być żołnierskie powinności. Organizatorzy wstępnie zapowiedzieli, że postarają się zorganizować spotkanie w piątek, 13 maja 2016 r., ale ostateczne ustalenia w kwestii tematyki, jak też daty zostaną potwierdzone pod koniec 2014 r. Podczas uroczystej kolacji ppłk Tomasz Gdak, dowódca 1 Batalionu Strzelców Podhalańskich, wręczył samodzielnym pracownikom nauki pamiątkowe upominki.

Po południu 26 czerwca część uczestników, która wyraziła na to chęć, wyruszyła do Lwowa, gdzie zorganizowano drugą, międzynarodową część Forum. W 2014 r. przypada setna rocznica wybuchu I wojny światowej. Była to okazja do zorganizowania wspólnie z lwowską Akademią Wojsk Lądowych Ukrainy spotkania polskich i ukraińskich historyków wojskowości, którego tematem przewodnim była „I wojna światowa i jej 
następstwa w aspekcie historyczno-wojskowym". Obrady w ramach tego sympozjum odbyły się w 27 czerwca w budynkach dydaktycznych AWL.

W części pierwszej obrady miały charakter plenarny, obejmujący 6 wystąpień. Doktor hab. prof. Ołeksij Suchyj przedstawił problematykę I wojny światowej we współczesnej ukraińskiej historiografii, dr hab. prof. UW Zdzisław Jagiełło omówił uwarunkowania ochrony polskiej granicy wschodniej II RP w latach 1918-1939, zaś dr hab. Halina Łach, w imieniu męża, dr. hab. prof. UWM Wiesława Łacha, wygłosiła referat dotyczący konfliktu polsko-litewskiego o Sejneńszczyznę w latach 1919-1920. Nastepnie dr hab. prof. Wiktor Hołubko omówił znaczenie traktatu brzeskiego jako wstępu do konfliktu polsko-ukraińskiego, zaś dr hab. prof. Władymyr Trofymowycz scharakteryzował ukraińskie i polskie kwestie w końcowym etapie I wojny światowej.

Następnie miało miejsce zwiedzanie zaplecza dydaktycznoszkoleniowego akademii, po czym przystąpiono do drugiej części obrad, tym razem w 4 sekcjach tematycznych. Sekcja pierwsza poświęcona została problemom historiografii, źródłoznawstwa oraz zabytkoznawstwa (7 referatów), druga obejmowała wystąpienia $\mathrm{z}$ zakresu stosunków międzynarodowych (8 referatów), trzecia zawierała prelekcje dotyczące nauki i techniki wojskowej (7 referatów), ostatnia zaś podejmowała problematykę sztuki wojennej (8 referatów).

$\mathrm{Na}$ zakończenie spotkania odbyło się plenarne podsumowanie obrad, w trakcie którego przyjęto wnioski i postulaty zawierające m.in. zapowiedź dalszych spotkań i badań dotyczących I wojny światowej i jej następstw, szczególnie w odniesieniu do Europy Środkowej i Wschodniej. Następnie, w imieniu komendanta Akademii Wojsk Lądowych gen. prof. Pawło Tkaczuka, prelegentom wręczono pamiątkowe dyplomy.

Kolejny dzień, 28 czerwca, poświęcony był już na część nieoficjalną, mianowicie zwiedzanie Lwowa oraz powrót uczestników do Rzeszowa. 